\title{
Epidemiology of female breast cancer in Niger: A literature review
}

\author{
Aissami Abdou ${ }^{1 *}$ and Guido Van Hal ${ }^{1}$ \\ Research Group of Social Epidemiology and Health Policy, University of Antwerp, Belgium. \\ Received 6 June, 2021; Accepted 26 July, 2021
}

\begin{abstract}
Breast cancer (BC) is a public health concern in sub-Saharan Africa with rising incidence and mortality. In Niger, BC is identified as the leading cancer morbidity and mortality within female population. Its epidemiological literature remains limited or not structured. The aim of this work was to summarize evidence in relation to epidemiology of female breast cancer in Niger. The idea was to know how much was published and available on the topic and what the gaps are. This review was conducted by considering all articles published on the epidemiology of breast cancer in Niger using The PRISMA (Preferred Reporting Items for Systematic Reviews and Meta-Analyses) model. A comprehensive search of material was performed using PubMed/Medline, African Journals Online, (AJOL), Web of Science, Google Scholar and Scopus/Elsevier. In total, 16 articles were initially screened, 14 full text articles were accessed for eligibility and 6 were included in the final review. None of the screened papers had clinical trial methodology or survival analysis. Moreover, no peer reviewed paper was found on breast cancer screening. The output of this review pointed out sustainable gaps in the field of epidemiology and public health research on BC in Niger. The country should have a national screening program and an updated analysis of cancer registry data. Effort is to be done on studies about cancer survival, feasibility and acceptability of alternative screening methods adapted to low-income countries, such as Niger.
\end{abstract}

Key words: Niger, breast cancer, public health, screening.

\section{INTRODUCTION}

Breast cancer (BC) stands as a public health concern in sub-Saharan Africa (Bray et al., 2018; Brinton et al., 2014; Bray et al., 2018, Azubuike et al., 2018). It remains the leading cancer in morbidity and mortality statistics especially in female population with prevailing geographical variations. On a wider perspective, according to the World Health Organization, (WHO) latest fact sheets (Globocan, 2018), North American, European and high-income Asian/Oceanian countries have the highest $\mathrm{BC}$ figures, sustaining higher incidence in the more-developed regions of the world. BC incidence and mortality (Age-Standardized Rates per 100,000 females) were reported to be the highest in Australia/New Zealand with 94.2 incidence and 12.6 mortality. Western Europe (Belgium, the Netherlands, and France) accounts for 92.6 and 15.5 incidence and mortality respectively. Northern

*Corresponding author. E-mail: aissamiabdou@gmail.com. Tel: +22791540000. 
European countries (Sweden, Finland, United Kingdom, and Denmark) have 90.1 incidences and 14.1 mortality. Elsewhere, northern American countries stands for 84.8 and 12.6 respectively. Estimates reached 56.8 and 13.4 in South American countries. Western Asia has 45.3 incidences and 13.6 mortality. Moreover, BC is the most frequently diagnosed cancer in women living in Gulf Cooperation Council countries (GCCCs). In the six GCCCs (Bahrain, Saudi Arabia, Kuwait, Oman, Qatar and the United Arab Emirates), BC is the greatest cause of cancer incidence and mortality, Tanner and Cheung (2020).

In the African region, Northern Africa has the highest estimates with 48.9 incidences and 18.4 mortality. (Bray et al., 2018), outlined that Western Africa to which Niger Republic belongs has 37.3 and 17.8 incidence and mortality respectively. It should be noted that lowest figures were observed in the middle Africa (27.9 and 15.8) and south-central Asia (25.9 and 13.6) regions. According to the latest 2012 Niger population Census (Décret Nº 2011-059/PCSRD/ME/F DU 27 Janvier 2011), the country population is 17.138 .707 inhabitants with 8.518.818 men (49.7\%) and 8.619.889 women (50.3\%). The current population of Niger is 24.088.564, based on projections of the latest United Nations data (https://worldpopulationreview.com/countries/nigerpopulation/). Niger is also the largest country in West Africa. The 2020 population size grew up by $3.84 \%$ over the 2019 population, adding about 896,000 people to the population. About $69 \%$ of Niger population is rural while around $31 \%$ is urban. Age groups of $0-4$ years $(21.6 \%)$, $5-9$ years $(17.5 \%)$ and $10-14$ years $(12.6 \%)$ have the highest proportions in Niger population age structure. Citizens aged from 15 years old have a cumulative proportion of $48.3 \%$. People aged from 65 years old and above represent $3.1 \%$ of the population. Thus, Niger population is very young.

\section{LITERATURE REVIEW}

In Niger, BC has been identified as the first cause of cancer related incidence and mortality standing respectively for 18.3 and $14.6 \%$ of the overall cancer burden in the country (WHO; Cancer Country Profiles, 2020). The country does not yet have an operational "Cancer management guidelines" nor "Palliative care included in their operational, integrated NCD plan". Besides, there is no national "breast cancer screening program". The heath system capacity is yet to be strengthened. As an example, according to the latest WHO Cancer Country Profiles (2020), there is no availability of "PET or PET/CT scanners" nor "MRI scanners" in Niger. There is 2.3 "radiologists" and 1.2 "Public cancer centres" per 10,000 cancer patients in the country. Pathology services and Palliative care are rated as "generally not available" in the country by WHO.
Some studies (Zaki et al., 2013, Nayama et al., 2006) sketched basic description of cancer patients in the country without engaging into a deep epidemiological analysis of cancer disease. (Zouladeny et al., 2015) outlined younger age and late diagnosis as common features of breast cancer in Niger. Studies established that if women adopt early risk-reduction behaviors like physical activity, healthy diets, breastfeeding, nonextensive alcoholic beverage consumption to mention but a few, significant part of the breast cancer burden can be prevented through primary prevention (Colditz and Bohlke 2014; Graham and Kari, 2015). This is even more important in countries like Niger where sophisticated material like mammographic screening facilities are not widely available. According to WHO cancer country profile (2020), there was about 10.4 mammographs for 10.000 cancer patients on Niger Republic.

Various studies (Youlden et al., 2012; Samuel et al., 2017) have documented that BC prevalence and mortality are increasing in sub-Saharan African countries. In a paper by (Adeloye et al., 2018), it was stated that the overall pooled African crude incidence of BC from population-based registries was 24.5 per 100,000 . Whereas some neighboring countries of Niger such as Nigeria, Algeria and Burkina have archived BC burden, researchers in the country itself did not established extensive epidemiological BC literature. Burkina Faso has 12.3 and 9.1 age standardized incidence and mortality rates while Algeria has 22.3 and 11.4. In Nigeria, according to the latest WHO data, Breast Cancer Deaths reached 14,932 with an age adjusted Death Rate of 30.08 per 100,000 of population. Spell neighboring Niger Republic and sharing many socio demographic features, Nigeria is currently the most populated country in Africa and is projected to be the world's third most populous country (behind China and India) by the year 2050, according to a report released by the UN Department of Economic and Social Affairs. Niger remained the country with the word highest fertility rate with an outstanding growing population also.

The aim of this study trajectory work was to summarize evidence in relation to epidemiology of female breast cancer in Niger by scanning all published papers in the past. The idea was to know how much is available on the topic and what are the gaps in a prospective public health approach.

\section{METHODOLOGY}

This review has been conducted by considering all articles published in the past in Niger on epidemiology of breast cancer. The main search keywords used were "Breast cancer, women, public health, epidemiology, breast self-examination, maternity, screening, cancer de sein, dépistage, revue littéraire, and Niger ". The authors used various combinations supported by Boolean expressions AND/OR in the search engines. This comprehensive 
search of material was performed using PubMed/Medline, African Journals Online, (AJOL), Web of Science, Google Scholar and Scopus/Elsevier. We also conducted a general search scanning in Google and the online "catalogue collectif réseau bibliothèques du Niger". Moreover, the WHO (Globocan) website and discussion with cancer specialists in Niger was done to track relevant material. The research and scanning methodology thus involved online search using the material described above, physical material tracking in libraries and discussions with cancer specialists in Niger.

\section{Eligibility criteria}

Published papers and articles that went through peer review were included in the final section. The authors considered articles published both in English and French without filtering by the publication date. The articles included needed to have an abstract and full text available before being selected. Articles that were not published or did not undergo a peer review process were not included in the final selection. Moreover, papers whose methodology is not well described or not scientifically sound was not included. Some studies were considered methodologically not sound because the method section if it exists is not well described when reviewing them. Most of them were reports written by students from faculty of medicine, university of Niamey as one requirement to the fulfilment of their bachelor's degree in medicine. They did not go a peer review process nor are they published. They were mainly found in the "catalogue collectif réseau bibliothèques du Niger".

\section{RESULTS AND DISCUSSION}

The first result of this work is shown on Figure 1 with the summary of articles selection based on PRISMA model.

Globally, few articles were found published on the epidemiology of breast cancer in Niger. In total, 24 articles were initially scanned at identification stage; they subsequently proceeded by eliminating duplicates and remained with 14 articles. Other sources included authors' referrals on some articles and faculty of medicine students' referrals in their assignments or theses. In total, 14 full text articles were accessed for eligibility and 6 were specific to breast cancer including one on male breast cancer.

Table 1 shows scanned papers, both included and excluded, with reasons behind their exclusion. (Zaki et al., 2013) and (Nayama et al., 2006) reported a retrospective analysis of cancer registry data in Niger. The first article aim to identify the epidemiological and histological aspects of gynecological and breast cancer for the best care of patients while the second determined the various epidemiological characteristics of cancers (broadly) in Niger from 1992 to 2009. Both were retrospective descriptive approaches of breast cancer data.

(Nayama et al., 2006) explored 9 years (from 1992 to 2000) of Niger cancer registry data. They found out that gynecological and breast cancer represented $54.3 \%$ of women cancer and $33.1 \%$ of diagnosed cancer of both sexes. Patients mean age was 36.5 years. The most frequent site was breast $(40.4 \%)$ followed by cervix (26\%). On a more clinical/ histological profiling, the study stated that epithelial tumors represented $87 \%$, sarcoma $7.9 \%$ of cases while the other histological types $5.1 \%$.

(Zaki et al., 2013) explored 17 years (from 1992 to 2009) of cancer trends in Niger; broadly, they found an average age of $43 \pm 17.53$ years for breast cancer patients. Breast cancer was the most frequent female cancer; it represented $27.4 \%$ of all cancer cases followed by cervical cancer (13.4\%) and ovarian cancer ( $8.83 \%)$. Approximately $7 \%$ of the registered cases are due to childhood cancers. This is not broadly in line with the well-known representative percentage of childhood cancer of all cancers which is about $1 \%$. Different reasons could explain this, one of them in Niger context is the exactitude of patient's age as reported by parents during cancer registration. Sometimes, patients do not have official data birth certificate and data registry rely on oral information given by parents. Nevertheless, (Peko et al, 2004) reported a child average year of 7,9 in a study in Congo-Brazaville.

Forty- two percent of the cancers had cytological and histological confirmation. The carcinomas constituted $27.0 \%$, the most frequent histological type. (Zaki et al., 2013), consider the same period (from 1992 to 2009) and reported that BC represents $16.5 \%$ of all cancers collected over the study period and $27.4 \%$ of female cancers. It is diagnosed at an average age of 44.1 years in women. The 40-49 age group is the majority of women affected by this pathology. Approximately Forty- seven percent $(47.3 \%)$ of reported breast cancer cases had cytological and histological confirmation.

Zouladeny et al. (2015) outlined epidemiological and clinical profiles of breast diseases in Niger during the period of 2010-2013 at the National Hospital of Niamey. They identified 245 breast cancers with patients mean age of 45.4 ( \pm 13.26 years). Their paper reported younger age of breast cancer with $1 / 3$ of cancers under age 44 . While only $37.1 \%$ of cancers had histopathological confirmation, $90 \%$ of cancer patients presented at advanced stages and mastectomy was performed for $66 \%$ of breast cancers.

Laurent et al. (2019) conducted a case control study in women aged 15 to 49 from January 1st, 2012 to December in Niamey region, they identified 144 cases and 144 controls in medical records of "Maternité Issaka Gozobi" admission records and cancer registry of the Anatomopathological Laboratory of the Faculty of Health Sciences. They found that $\mathrm{BC}$ was associated with: age $\geq$ 35 years $\mathrm{OR}=1.97$ (1.16-3.35), oral contraceptive use $\mathrm{OR}=2.29(1.31-4.01)$ and breastfeeding $\mathrm{OR}=0.43(0.23$ $0.46)$.

Mamane et al. (2012) described the knowledge, attitudes and practices (KAP) of non-medical health professionals related to $\mathrm{BC}$ in different health care structures in Niamey. They included 112 health 


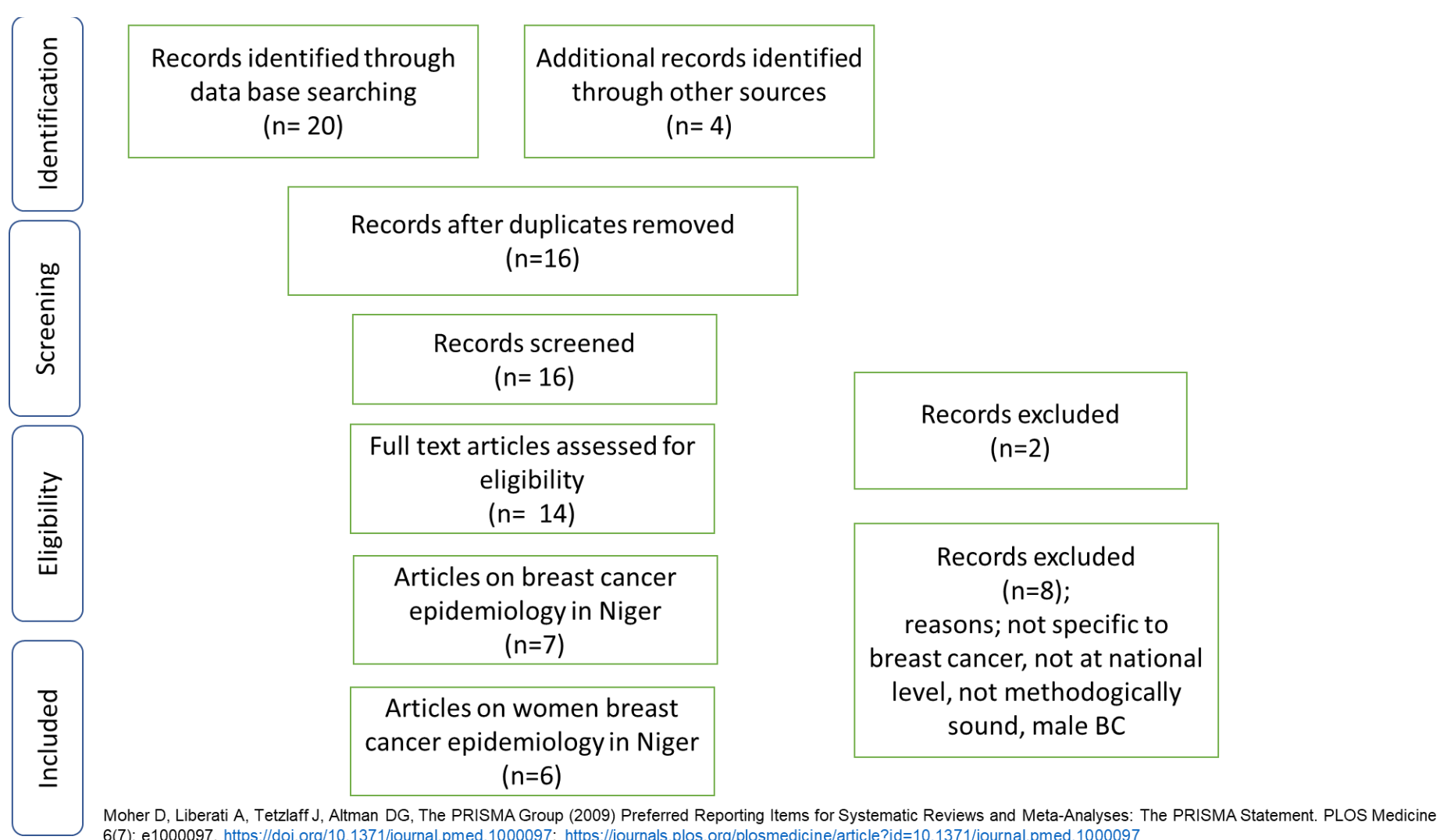

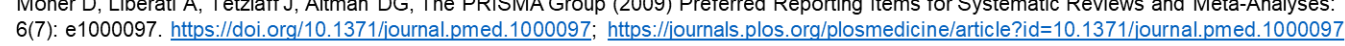

Figure 1. Article selection flowchart (based on PRISMA Model).

professionals (non-physicians) from 10 health centers in Niamey and found that they were mostly insufficiently informed about BC and diagnostic methods. They recommended continuing education for non-medical health professionals on $\mathrm{BC}$ and involvement of midwives in the management of $\mathrm{BC}$ in order to improve the early detection.

Globally, the authors could not find extensive literature on epidemiology of breast cancer or its public health determinants in Niger. Some of the published papers we found (Nayama et al., 2006; Zaki et al., 2013; Zouladeny et al., 2015) framed descriptive retrospective analysis of breast cancer features in Niger. Useful characteristics and basic description of cancer profiles was done but the papers did not explore in depth epidemiological analysis of breast cancer or its public health ramifications. It should be noted that no paper was found on breast cancer clinical trials in Niger. No peer reviewed paper was found on screening even if some activities of screening are organized in the country.

While Mamane et al. (2012) presented the knowledge, attitudes and practices (KAP) of non-medical health professionals related to breast cancer in different health care structures in Niamey. (Aissami et al., 2020) analyzed the KAP of women in Niamey and Zinder. Both studies pointed to an insufficient level of awareness of women and health professionals on breast cancer especially knowledge of risk factors. Both articles identified midwives as an essential link in the chain of breast cancer management. (Aissami et al., 2020) recommended that awareness programs should promote clinical breast examination as mammography is not common and promote early detection procedures. Mamane et al, (2012) recommended continuing education for non-medical health professionals on breast cancer and involvement of midwives in the management of breast cancer in order to improve the early detection. (Aissami et al., 2020) found that age, clinical breast examination, breastfeeding, history of participation in breast cancer screening and areas of residence were associated with awareness of breast cancer. They reported an awareness level of $41.2 \%(37.5-45.0)$ in Niger women.

Guthega et al. (2019) using the PRISMA model found two papers on validation of the Breast Cancer Awareness Measure tool in Kenya (Wachira, 2017; Violet et al., 2015). (Aissami et al., 2020) performed a validation of Breast cancer awareness Measure, BCAM tool in Niger. They found that the BCAM was an acceptable, reliable and valid tool when applied to women and midwives in Niger. Nevertheless, it requires some refining to better suit some social and contextual factors. (Azubuike et al., 
2018) published a review titled "Rising global burden of breast cancer: the case of sub-Saharan Africa (with emphasis on Nigeria) and implications for regional development". Nigeria shares some socio-economic features with Niger, the two countries being neighbors whereas this could have relevance for Niger context, we could not find in depth analysis and review of this type done in Niger. It comes out from this study that globally, about $25 \%$ and $15 \%$ of all new cancer cases and cancer deaths respectively among females were due to breast cancer and Africa currently had the highest agestandardized breast cancer mortality rate globally, with the highest incidence rates being recorded within the sub-Saharan African sub-region. Certain factors such as westernized diet, urbanization and possibly increasing awareness had been implicated, though their specific contributions were yet to be fully established.

Ojewusi et al. (2016) conducted a systematic

review on breast cancer awareness, attitude and screening practices in Nigeria, and found up to 40 articles that were included. They found that the majority of the respondents were aware of breast cancer as a disease entity. Electronic media and television (TV) were the leading sources of information on breast cancer in Nigeria, while use of leaflets and internet were unpopular in this regard. Moreover, their results pointed out deficiency in screening practices even among those who were aware of the screening methods. They stated that "campaigns that couple information with other services are more likely to bring sustained changes in behavior." Mammography and other sophisticated diagnostic tests are not that much available in Niger, as of the moment this paper is being written, no single mammography device is available in public health structures in Niger. A national center on Cancer (Centre National de Lutte contre le Cancer, CNLC) is created; it has chemotherapy service but does not yet have radiotherapy or mammography services. In the absence of mammography in low income countries like Niger alternative screening options like clinical breast examination or breast self-examination if well performed are suggested (Black and Richmond, 2019; Onyije et al., 2010).

Laurent et al. (2019) recommended an awareness program on breast cancer towards women. Specifically, regarding the importance of breastfeeding as it was found to lower the risk of breast cancer. Studies on factors associated to BC in Niger are limited. Laurent et al. (2019) found that $B C$ was associated with: age $\geq 35$ years $\mathrm{OR}=1.97(1.16-3.35)$ and breastfeeding $\mathrm{OR}=0.43$ (0.23-0.46). (Aissami et al., 2020) found that age (OR = breastfeeding $3.34(2.12-5.26)$ were associated with BC awareness.

They could not find studies on feasibility and acceptability of alternative screening methods adapted to low resources countries. Given the rising of cancer incidence in the region (Azubuike et al., 2018; Sambo et al., 2012), this would, however, be very welcome.

\section{Conclusion}

6 papers were included in the final stage of this review following the PRISMA model (Table 1). No paper was found on BC clinical trials from Niger out of this review. No evidence of published paper was found on breast cancer screening in Niger. While Screening of breast and cervical cancer is conducted in Niger, its structured documentation is yet to be done given its importance in cancer prevention in this Low-Income Country which does not yet have a national "breast cancer screening program". One important hole in breast cancer epidemiology literature review is "Breast cancer survival" in Niger, no studies was found on survival analysis and information on "Quality of mortality registration" is not is not well known in Niger.

It was reported from retrospective descriptive review of BC data in Niger from 1992 to 2009 that gynecological and breast cancers represented $54.3 \%$ of women cancer with BC representing $16.51 \%$ of all cancers. Patients mean age was 43 years. Some studies pointed younger age and late presentation as main features of BC cases in Niger. Elsewhere, BC was found to be associated with age, oral contraceptive use and inversely with breastfeeding. Knowledge, attitudes and practices (KAP) of women and non-medical health professionals related to $\mathrm{BC}$ were mostly insufficient. Mammography and other sophisticated diagnostic tests are not that much available in Niger. An article on validation of a Breast Cancer Awareness Measure, BCAM for women and midwives' tool was reviewed.

The output of this review pointed out sustainable gaps in the field of epidemiology and public health research on BC in Niger. While records and milestones are available on some clinical features of the disease, its epidemiological exploitation using advanced biostatistical or epidemiological methods are very limited.

\section{RECOMMENDATION}

1) Research should be conducted on survival of breast cancer in Niger as no material was found in this review an 'Quality of mortality registration" is not well known in Niger

2) In Niger, effort is to be done on studies about feasibility and acceptability of alternative screening methods adapted to low resources countries.

3) Given the specific profile of the country (highest fertility rate of the world, one of the youngest populations, one of the largest countries in Africa, poor workforce in public health), national and international research in public health in Niger should be enhanced and supported, the country could be included in multicentric BC clinical 
Table 1. Papers included and excluded in the review.

\begin{tabular}{|c|c|c|c|c|c|c|c|c|}
\hline $\mathbf{n}$ & Author(s) & Year & Journal/Source & Methods & Objectives & Title & $\begin{array}{l}\text { Included/excluded } \\
\text { reason }\end{array}$ & \\
\hline 1 & $\begin{array}{l}\text { Laurent et } \\
\text { al. }\end{array}$ & 2019 & $\begin{array}{l}\text { Vol. } 42 \text { No. } 2 \text { (2019) ajol. } \\
\text { elSSN: } \\
\text { print ISSN: } 1011-6028\end{array}$ & $\begin{array}{l}\text { Case control } \\
\text { study }\end{array}$ & $\begin{array}{l}\text { Identify factors associated with breast } \\
\text { cancer in women aged } 15 \text { to } 49 \text { years } \\
\text { and contribute to reduce its incidence. }\end{array}$ & $\begin{array}{l}\text { Facteurs associés au cancer du sein chez les femmes } \\
\text { âgées de } 15 \text { à } 49 \text { ans de la Maternité Issaka Gazobi de } \\
\text { la région de Niamey, janvier } 2012 \text { à décembre } 2016\end{array}$ & Included & \\
\hline 2 & $\begin{array}{l}\text { Mamata } \\
\text { AA }\end{array}$ & 2019 & $\begin{array}{l}106203064 \\
\text { Memoire/Thèse } \\
\text { 03. FSS }\end{array}$ & $\begin{array}{l}\text { Restrospective } \\
\text { descriptive } \\
\text { study }\end{array}$ & $\begin{array}{l}\text { Analyze epidemiological, clinical, } \\
\text { therapeutic and prognostic } \\
\text { characteristics of } \\
\text { breast cancer in postmenopausal women }\end{array}$ & $\begin{array}{l}\text { Quelques aspects du cancer du sein de la femme } \\
\text { ménopausée au Niger : étude prospective à propos de } \\
31 \text { cas }\end{array}$ & $\begin{array}{l}\text { Excluded/ not } \\
\text { reviewed } \\
\text { methodologically } \\
\text { sound }\end{array}$ & $\begin{array}{r}\text { peer } \\
\text { or } \\
\text { not }\end{array}$ \\
\hline 3 & $\begin{array}{l}\text { Ousmane } \\
\mathrm{Al}\end{array}$ & 2019 & $\begin{array}{l}106203147 \\
\text { Memoire/Thèse } \\
\text { 03. FSS }\end{array}$ & $\begin{array}{l}\text { Restrospective } \\
\text { descriptive } \\
\text { study }\end{array}$ & $\begin{array}{l}\text { Write the epidemiology of the different } \\
\text { types of cancer recorded in the anatomy } \\
\text { and cytology laboratory } \\
\text { of Niamey }\end{array}$ & $\begin{array}{l}\text { Registre des cancers : Fréquence relative des cancers } \\
\text { au Niger de } 2008 \text { à } 2017 \text { Etude rétrospective à propos } \\
\text { de } 5529 \text { cas }\end{array}$ & $\begin{array}{l}\text { Excluded /not } \\
\text { reviewed } \\
\text { methodologically } \\
\text { sound }\end{array}$ & $\begin{array}{r}\text { peer } \\
\text { or } \\
\text { not }\end{array}$ \\
\hline 4 & $\begin{array}{l}\text { Aminata } \\
\mathrm{HH}\end{array}$ & 2019 & $\begin{array}{l}06203104 \\
\text { Memoire/Thèse } \\
\text { 03. FSS }\end{array}$ & $\begin{array}{l}\text { Case study and } \\
\text { literature review }\end{array}$ & $\begin{array}{l}\text { Observation of the first case of breast } \\
\text { carcinosarcoma diagnosed at the Issaka } \\
\text { Gazoby Maternity Hospital in Niamey } \\
\text { with a literature review. }\end{array}$ & $\begin{array}{l}\text { Carcinosarcome du sein au Niger à propos d'un cas et } \\
\text { revue de la littérature }\end{array}$ & $\begin{array}{l}\text { Excluded /not } \\
\text { reviewed } \\
\text { methodologically } \\
\text { sound }\end{array}$ & $\begin{array}{r}\text { peer } \\
\text { or } \\
\text { not }\end{array}$ \\
\hline 5 & $\begin{array}{l}\text { Jacob dit } \\
\text { Yacouba } \\
\text { PO }\end{array}$ & 2016 & $\begin{array}{l}106202624 \text { PHI } \\
\text { Memoire/Thèse } \\
\text { 03. FSS }\end{array}$ & $\begin{array}{l}\text { Cross sectional } \\
\text { descriptive } \\
\text { study }\end{array}$ & $\begin{array}{l}\text { Assess knowledge, } \\
\text { attitudes and perception of women of } \\
\text { childbearing age towards breast cancer } \\
\text { in the urban community of Niamey }\end{array}$ & $\begin{array}{l}\text { Connaissances, attitudes et perception des femmes en } \\
\text { âge de procréer vis-à-vis du cancer du sein dans la } \\
\text { communauté urbaine de Niamey en } 2016 \text { Etude } \\
\text { transversale à propos de } 192 \text { femmes enquêtées dans } \\
\text { la ville de Niamey en } 2016\end{array}$ & $\begin{array}{l}\text { Excluded /not } \\
\text { reviewed } \\
\text { methodologically } \\
\text { sound }\end{array}$ & $\begin{array}{r}\text { peer } \\
\text { or } \\
\text { not }\end{array}$ \\
\hline 6 & $\begin{array}{l}\text { Zouladeny } \\
\text { H et al. }\end{array}$ & 2015 & $\begin{array}{l}\text { Intl J Cancer Oncol 2(2): 1- } 6 \text {. } \\
\text { doi:10.15436/2377- } \\
\text { 0902.15.015 }\end{array}$ & Mixed methods & $\begin{array}{l}\text { Characterizing epidemiological and } \\
\text { clinical profiles of breast diseases in } \\
\text { Niger during the period of } 2010-2013\end{array}$ & $\begin{array}{l}\text { Epidemiologic and Clinical Profiles of Breast Diseases in } \\
\text { Niger }\end{array}$ & Included & \\
\hline 7 & $\begin{array}{l}\text { Salamatou } \\
\text { et al., }\end{array}$ & 2013 & $\begin{array}{l}\text { Bulletin du Cancer } \\
\text { Volume 100, Issue 2, February } \\
\text { 2013, Pages 127-133 }\end{array}$ & $\begin{array}{l}\text { Retrospective ; } \\
\text { descriptive } \\
\text { study }\end{array}$ & $\begin{array}{l}\text { Determine the various epidemiological } \\
\text { characteristics of cancers in Niger from } \\
1992 \text { to } 2009 \text {. }\end{array}$ & Épidémiologie des cancers au Niger, 1992 à 2009 & Included & \\
\hline 8 & $\begin{array}{l}\text { Zaki H, et } \\
\text { al. }\end{array}$ & 2013 & $\begin{array}{l}\text { Journal Africain du Cancer } \\
/ 10.1007 / \mathrm{s} 12558-013-0274-9 .\end{array}$ & $\begin{array}{l}\text { Retrospective ; } \\
\text { descriptive } \\
\text { study }\end{array}$ & $\begin{array}{l}\text { Present epidemiological profile of breast } \\
\text { cancer in Niger }\end{array}$ & $\begin{array}{l}\text { Profil épidémiologique et anatomopathologique du } \\
\text { cancer du sein au Niger. }\end{array}$ & Included & \\
\hline 9 & $\begin{array}{l}\text { Mamane, A } \\
\text { et al. }\end{array}$ & 2012 & $\begin{array}{l}\text { Journal Africain du Cancer / } \\
\text { African Journal of Cancer } \\
\text { volume } 4, \text { pages156-163 } \\
\text { (2012) }\end{array}$ & $\begin{array}{l}\text { Cross sectional } \\
\text { study }\end{array}$ & $\begin{array}{l}\text { Describe the knowledge, attitudes and } \\
\text { practices (KAP) of non-medical health } \\
\text { professionals related to breast cancer in } \\
\text { different health care structures in Niamey }\end{array}$ & $\begin{array}{l}\text { La prise en charge du cancer du sein au Niger : } \\
\text { connaissances, attitudes et pratiques des professionnels } \\
\text { de santé non médecins de Niamey, Niger, } 2010\end{array}$ & Included & \\
\hline 10 & $\begin{array}{l}\text { Nafissatou } \\
\text { BC }\end{array}$ & 2012 & $\begin{array}{l}06201982 \text { BOU } \\
\text { Memoire/Thèse 03. FSS }\end{array}$ & $\begin{array}{l}\text { Cross sectional } \\
\text { study }\end{array}$ & $\begin{array}{l}\text { assess the knowledge, attitudes and } \\
\text { practices of } \\
\text { health care professionals towards breast } \\
\text { cancer }\end{array}$ & $\begin{array}{l}\text { Connaissances, attitudes et pratiques du personnel } \\
\text { soignant du Centre Hospitalier Régional de Maradi sur } \\
\text { le cancer du sein }\end{array}$ & $\begin{array}{l}\text { Excluded /not } \\
\text { reviewed } \\
\text { methodologically } \\
\text { sound }\end{array}$ & $\begin{array}{r}\text { peer } \\
\text { or } \\
\text { not }\end{array}$ \\
\hline
\end{tabular}


Table 1.contd.

\begin{tabular}{|c|c|c|c|c|c|c|c|}
\hline 11 & Omar GB & 2011 & $\begin{array}{l}\text { 06201836GAR } \\
\text { Memoire/Thèse 03.FSS }\end{array}$ & $\begin{array}{l}\text { Restrospective } \\
\text { descriptive } \\
\text { study }\end{array}$ & $\begin{array}{l}\text { Describe the epidemiological and } \\
\text { histopathological aspects of breast } \\
\text { cancer }\end{array}$ & $\begin{array}{l}\text { Cancer du sein au Niger : aspects épidémiologiques et } \\
\text { histopathologiques, étude rétrospective de } 1992 \text { à } 2009 \text { à } \\
\text { propos de } 1157 \text { cas recensés au niveau du laboratoire } \\
\text { d'anatomie pathologique de l'hôpital national lamorde. }\end{array}$ & $\begin{array}{l}\text { Excluded/ not peer } \\
\text { reviewed or } \\
\text { methodologically not sound }\end{array}$ \\
\hline 12 & $\begin{array}{l}\text { Ramatou } \\
\text { SB }\end{array}$ & 2009 & $\begin{array}{l}\text { 106201692SEY } \\
\text { Memoire/Thèse 03. FSS }\end{array}$ & $\begin{array}{l}\text { Cross } \\
\text { sectional study }\end{array}$ & $\begin{array}{l}\text { Attract the attention of all } \\
\text { stakeholders to strengthen } \\
\text { awareness and improve the } \\
\text { prognosis of breast cancer }\end{array}$ & $\begin{array}{l}\text { Effets de la sensibilisation sur le cancer du sein chez les } \\
\text { femmes dans la ville de Tillabéry }\end{array}$ & $\begin{array}{l}\text { Excluded /not peer } \\
\text { reviewed or } \\
\text { methodologically not sound }\end{array}$ \\
\hline 13 & Sani R et al. & 2009 & $\begin{array}{l}\text { The Pan African medical } \\
\text { journal } \\
\text { 10.4314/pamj.v3i1.52454 }\end{array}$ & unclear & $\begin{array}{l}\text { Report clinicopathological } \\
\text { characteristics, treatment patterns, } \\
\text { and outcomes of male breast cancer }\end{array}$ & $\begin{array}{l}\text { Male breast cancer: } 22 \text { case reports at the National } \\
\text { Hospital of Niamey-Niger (West Africa) }\end{array}$ & $\begin{array}{l}\text { Excluded/paper rather on } \\
\text { male breast cancer, } \\
\text { methods not well described }\end{array}$ \\
\hline 14 & $\begin{array}{l}\text { Nayama et } \\
\text { al. }\end{array}$ & 2006 & $\begin{array}{l}\text { Mali Med. 2006; } 21 \\
\text { (3):43-9. French. PMID: } \\
\text { 19435008. }\end{array}$ & $\begin{array}{l}\text { Retrospective; } \\
\text { descriptive } \\
\text { study }\end{array}$ & $\begin{array}{l}\text { Identify the epidemiological and } \\
\text { histological aspects of gynecological } \\
\text { and breast cancer for a best care of } \\
\text { patients. }\end{array}$ & $\begin{array}{l}\text { Epidemiological and histological aspects of gynecologic } \\
\text { and breast cancer in the pathology department of Niamey's } \\
\text { Health Faculty, Niger }\end{array}$ & Included \\
\hline
\end{tabular}

trials on occasion. Investment in research on cancer in general and BC could bring clarity and inform clinicians both on prevention and management of cancer in the country still struggling for its epidemiological transition.

4) The latest epidemiological description of breast cancer registry data that we found concerned data from 1992 to 2009 and was published in 2013, about a decade ago, there is need to produce updated analyses of cancer registry data in Niger.

\section{LIMITATION}

The limitation of this work as literature review included its potential for selection bias from scanning and analysis of articles. The paper focused on female BC and did not explore papers on clinical features of breast cancer in Niger. Although it is possible that we omitted some articles, the paper was written considering the methodology described and the availability of materials. The study meets ethical requirements on literature review; it did not include collection on persons or any authorization from third parties concerned.

\section{CONFLICT OF INTERESTS}

The authors have not declared any conflicts of interests.

\section{REFERENCES}

Aissami A, Van Hal G, Dille I (2020). Awareness, attitudes and practices of women in relation to breast cancer in Niger. Heliyon 6(7):e04316.https://doi.org/10.1016/j.heliyon. 2020.e04316.

Adeloye D, Sowunmi OY, Jacobs W, David RA, Adeosun AA, Amuta AO, Chan KY (2018). Estimating the incidence of breast cancer in Africa: a systematic review and metaanalysis. Journal of Global Health 8(1).

Aminata HH (2019). "Carcinosarcome du sein au niger a propos d'un cas et revue de la littérature" https://mediathequesniger.org/index.php?|vl=notice_display \&id=127550. not published
Azubuike SO, Muirhead C, Hayes L, McNally R (2018). Rising global burden of breast cancer: the case of sub-Saharan Africa (with emphasis on Nigeria) and implications for regional development: a review. World Journal of Surgical Oncology 16(1):1-13. https://doi.org/10.1186/s12957-0181345-2

Black E, Richmond R (2019).Improving early detection of breast cancer in sub-Saharan Africa: why mammography may not be the way forward. Globalization and health 15(1):1-11.PMID: 30621753; PMCID: PMC6325810.

Brinton LA, Figueroa JD, Awuah B, Yarney J, Wiafe S, Wood SN,Clegg-Lamptey JN (2014). Breast cancer in SubSaharan Africa: opportunities for prevention. Breast cancer research and treatment 144(3):467-478.

Bray F, Ferlay J, Soerjomataram I, Siegel RL, Torre LA, Jemal A (2018). Global cancer statistics 2018: GLOBOCAN estimates of incidence and mortality worldwide for 36 cancers in 185 countries. CA: a cancer journal for clinicians 68(6):394-424. Globocan: http://globocan.iarc.fr/old/burden.asp?selection_pop $=14256$ 2\&Text-

$\mathrm{p}=$ Niger\&selection_cancer $=3152 \&$ Textc $=$ Breast $\& p$ Year $=3 \& \mathrm{t}$ ype $=0 \&$ window $=1 \&$ submit= Execute_https://doi.org/10.1684/ bdc.2013.1699

Colditz GA, Bohlke K (2014).Priorities for the primary prevention of breast cancer. CA: a cancer journal for clinicians 64(3):186-194.

Jacob dit Yacouba PO (2016) " Connaissances, attitudes et perception des femmes en âge de procréer vis-à-vis du 
cancer du sein dans la communauté urbaine de Niamey en 2016 Etude transversale à propos de 192 femmes enquêtées dans la ville de Niamey en 2016" https://mediathequesniger.org/index.php?|v|=more_results\&mode=keyword\&user_query= Connaissances\&tags $=0 \mathrm{k}$ not published http://www.cansa.org.za/files/2017/12/Poster-Symptom-awarenessmeasures-for-breast-and-cervical-cancer-in-Sub-Saharan-Africa.pdf

Laurent CBM, Yanogo PK, Hassane N, Antara S, Sawadogo B, Meda N (2019). Facteurs associés au cancer du sein chez les femmes âgées de 15 à 49 ans de la Maternité Issaka Gazobi de la région de Niamey, janvier 2012 à décembre 2016: Étude cas-témoins. Science et Technique, Sciences de la Santé 42(2):99-105.

Mamane A, Bhatti JA, Savès M, Alioum A, Jutand MA, Hadiza-Jackou D, Sasco AJ(2012). La prise en charge du cancer du sein au Niger: connaissances, attitudes et pratiques des professionnels de santé non médecins de Niamey, Niger, 2010. Journal Africain du Cancer/African Journal of Cancer 4(3):156-163. https://doi.org/10.1007/s12558-012-0210-4)

Nafissatou BS (2012). "Connaissances, attitudes et pratiques du personnel soignant du Centre Hospitalier Régional de Maradi sur le cancer du sein" https://mediathequesniger.org/index.php?|v|=notice_display\&id=129014, not published.

Nayama M, Nouhou H, Souna-Madougou K, Idi N, Garba M, Tahirou A, Touré A (2006). Cancers gynecologiques et mammaires: aspects epidemiologiques et histologiques dans le service d'anatomie et cytologie pathologique de la Faculte des Sciences et de la Sante de Niamey Niger [Epidemiological and histological aspects of gynecologic and breast cancer in the pathology department of Niamey's Health Faculty, Niger]. Mali Medical 21(3):43-49. French. PMID: 19435008 .

Ojewusi AA, Obembe T, Arulogun OS, Olugbayela T (2016). Breast cancer awareness, attitude and screening practices in Nigeria: $A$ systematic review 7(2):11-25.

Omar GB (2011) " cancer du sein au niger: aspects epidemiologiques et histopathologiques etude rétrospective de 1992 à 2009 à propos de 1157 cas recensés au niveau du laboratoire d'anatomie pathologique de l'Hôpital National Lamordé." https://mediathequesniger.org/index.php?|v|=more_results\&mode=ke yword\&user_query=Histopathologie\&tags $=0 \mathrm{k}$, not published

Onyije FM, Zenebo VC, Oboma YI (2010). Knowledge and practice of breast cancer self examination among female students in tertiary institutions in Nigeria. Continental Journal of Biomedical Science 4:75-82.

Ousmane Al (2019). " Registre des cancers: Fréquence relative des cancers au Niger de 2008 à 2017 Etude rétrospective à propos de 5529 cas " https://mediathequesniger.org/index.php?|v|=more_results\&autolevel $1=1$, not published
Ramatou SB (2009)., "Effets de la sensibilisation sur le cancer du sein chez les femmes dans la ville de tillabery" https://mediathequesniger.org/index.php?|vl=notice_display\&id=1295 76 , not published

Samuel NC, Keneth NN, Tsoka-Gwegweni JM (2017) Breast cancer among women in sub-Saharan Africa: prevalence and a situational analysis. Southern African Journal of Gynaecological Oncology 9(2):28-30.

Youlden DR, Cramb SM, Dunn NA, Muller JM, Pyke CM, Baade PD (2012). The descriptive epidemiology of female breast cancer: an international comparison of screening, incidence, survival and mortality. Cancer epidemiology 36(3):237-248.

Peko JF, Moyen G, Gombe-Mbalawa C (2004). Les tumeurs solides malignes de l'enfant à Brazzaville: aspects épidémiologique et anatomo-pathologique. Bull soc pathol exot 97(2):117-118.

Zaki HM, Garba-Bouda O, Garba SM, Nouhou H (2013). Profil épidémiologique et anatomopathologique du cancer du sein au Niger. Journal Africain du Cancer/African Journal of Cancer 5(4):185-191.

Sambo LG, Dangou JM, Adebamowo C, Albrecht CF, Gombé-Mbalawa C, Ngoma T, Sambo BH (2012). Cancer in Africa: a preventable public health crisis. Journal Africain Du Cancer/African Journal of Cancer 4(2):127-136. https://doi.org/10.1007/s12558-012-0212-2

Wachira J, Busakhala A, Chite F, Naanyu V, Kisuya J, Otieno G, Keter A, Mwangi A, Inui T.(2017). "Refining a questionnaire to assess breast cancer knowledge and barriers to screening in Kenya: Psychometric assessment of the BCAM".BMC Health Services Research17(1):1-11.

World Health Organization (WHO) (2020). Cancer Country Profiles, 2014, http://www.who.int/cancer/country-profiles/ner_en.pdf?ua=1, accessed on 22-07-2018

Zouladeny H, Dille I, Wehbi NK, Kim J, Soliman AS (2015). Epidemiologic and clinical profiles of breast diseases in Niger. International Journal of Cancer and Oncology 2(2). 